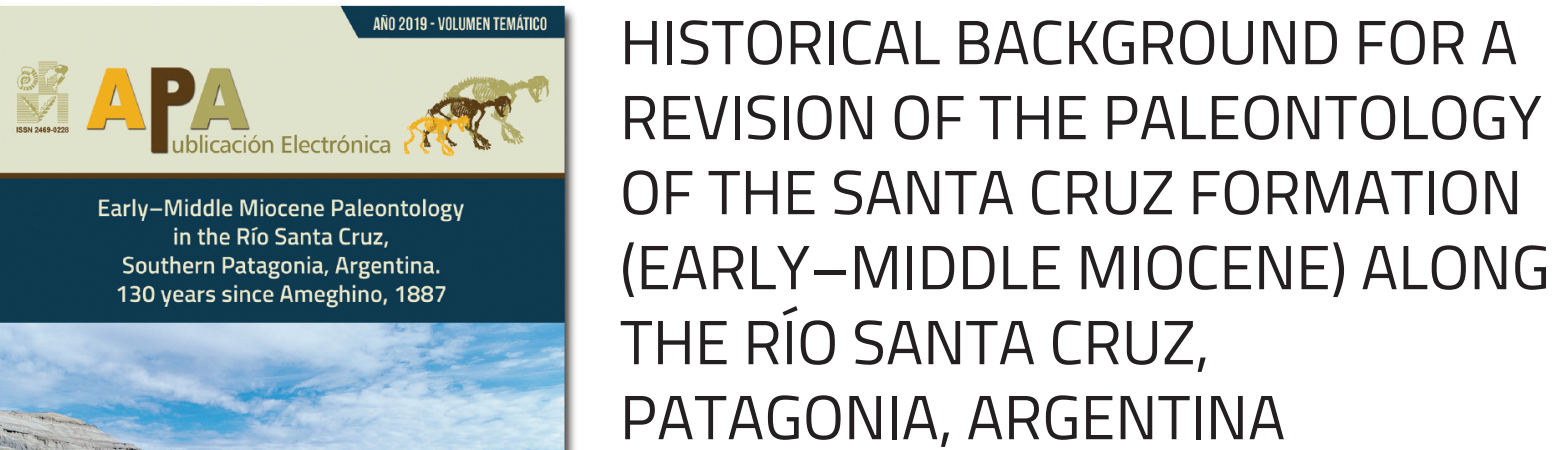

JUAN C. FERNICOLA ${ }^{1,2,3}$

M. SUSANA BARGO1,4,5

SERGIO F. VIZCAIINO 3,4

RICHARD F. KAYG

'Sección Paleontología de Vertebrados, Museo Argentino de Ciencias Naturales "Bernardino Rivadavia". Av. Ángel Gallardo 470, 1405DJR Ciudad Autónoma de Buenos Aires, Argentina.

2Universidad Nacional de Luján, Departamento de Ciencias Básicas. Ruta 5 y Avenida Constitución, 6700 Luján, Buenos Aires, Argentina.

${ }^{3}$ Consejo Nacional de Investigaciones Científicas y Técnicas (CONICET).

4División Paleontología Vertebrados, Museo de La Plata, Unidades de Investigación Anexo Museo, Facultad de Ciencias Naturales y Museo. Av. 60 y 122, B1904, La Plata, Argentina.

${ }^{5}$ Comisión de Investigaciones Científicas Provincia de Buenos Aires (CIC).

${ }^{6}$ Department Evolutionary Anthropology, Box 90383, Duke University. Durham, NC 27708, USA.

Recibido: 11 de julio 2019 - Aceptado: 18 de septiembre 2019

Para citar este artículo: Juan Carlos Fernicola, M. Susana Bargo, Sergio F. Vizcaíno, and Richard F. Kay (2019). Historical background for a revision of the paleontology of the Santa Cruz Formation (Early-Middle Miocene) along the Río Santa Cruz, Patagonia, Argentina. Publicación Electrónica de la Asociación Paleontológica Argentina 19 (2): $1-13$.

Link a este artículo: http://dx.doi.org/10.5710/PEAPA.18.09.2019.300

DESPLAZARSE HACIA ABAJO PARA ACCEDER AL ARTÍCULO

Otros artículos en Publicación Electrónica de la APA 19(2):

\section{Chornogubsky et al.}

THE METATHERIA FROM THE RÍO SANTA CRUZ (SANTA CRUZ FORMATION, EARLY-MIDDLE MIOCENE, ARGENTINA): HISTORY AND NEW FINDINGS

\section{G. Schmidt et al.}

LITOPTERNA (MAMMALIA) FROM THE SANTA CRUZ FORMATION (EARLY-MIDDLE MIOCENE) AT RÍO SANTA CRUZ, SOUTHERN ARGENTINA

Asociación Paleontológica Argentina Maipú $6451^{\circ}$ piso, C1006ACG, Buenos Aires República Argentina Tel/Fax (54-11) 4326-7563 Web: www.apaleontologica.org.ar

\section{R.F. Kay, J.M.G. Perry}

NEW PRIMATES FROM THE RÍO SANTA CRUZ AND RÍO BOTE (EARLY-MIDDLE MIOCENE), SANTA CRUZ PROVINCE, ARGENTINA 


\title{
HISTORICAL BACKGROUND FOR A REVISION OF THE PALEONTOLOGY OF THE SANTA CRUZ FORMATION (EARLY-MIDDLE MIOCENE) ALONG THE RÍO SANTA CRUZ, PATAGONIA, ARGENTINA
}

\author{
JUAN C. FERNICOLA ${ }^{1,2,3}$, M. SUSANA BARGO 4,5 , SERGIO F. VIZCAIINO ${ }^{3,4}$, AND RICHARD F. KAY6
}

\author{
'Sección Paleontología de Vertebrados, Museo Argentino de Ciencias Naturales "Bernardino Rivadavia". Av. Ángel Gallardo 470, 1405DJR Ciudad Autónoma de \\ Buenos Aires, Argentina. jctano@yahoo.com \\ 2Universidad Nacional de Luján, Departamento de Ciencias Básicas. Ruta 5 y Avenida Constitución, 6700 Luján, Buenos Aires, Argentina. \\ ${ }^{3}$ Consejo Nacional de Investigaciones Científicas y Técnicas (CONICET). \\ 4División Paleontología Vertebrados, Museo de La Plata, Unidades de Investigación Anexo Museo, Facultad de Ciencias Naturales y Museo. Av. 60 y 122, B1904, \\ La Plata, Argentina.msbargo@fcnym.unlp.edu.ar; vizcaino@fcnym.unlp.edu.ar \\ ${ }^{5}$ Comisión de Investigaciones Científicas Provincia de Buenos Aires (CIC). \\ ${ }^{6}$ Department Evolutionary Anthropology, Box 90383, Duke University. Durham, NC 27708, USA. richard.kay@duke.edu
}

\begin{abstract}
In 1887, Carlos Ameghino carried out the first geological and paleontological expedition to the Río Santa Cruz (RSC), Patagonia, Argentina. Between 1887 and 1889, Florentino Ameghino studied the fossils obtained by Carlos, founding more than 120 taxa and establishing his Formación Santacruceña and Piso Santacruceño. In 1888, F. Ameghino was exonerated from the Museo de La Plata and replaced by Alcides Mercerat in 1889, starting a strong competition for the Santacrucian fossils, which since 1890 were obtained mainly on the Atlantic coast. Until 1894, Ameghino and Mercerat founded more than 500 mammal species, of which $80 \%$ correspond to Ameghino who, later, synonymized almost all Mercerat species. At the end of the $19^{\text {th }}$ century, foreign explorers visited Patagonia, but they did not collect in the RSC. So the largest RSC collections were made until 1889. The Santacrucian collections of the $19^{\text {th }}$ century have vague and in some cases contradictory geographical information. This is true for the Santacrucian species reassigned by F. Ameghino to the Notohippidian, an association that he located northwest of the RSC. Recent analyses show that several of these specimens were collected southwest of the RSC. These and other facts demonstrate the inconvenience of using the data from the old collections in biostratigraphic and paleoecological studies without a critical analysis of the history of their provenance. Since 2003, a research program was launched that promoted biostratigraphic and paleoecological studies of the Santa Cruz Formation (SCF). This Thematic Volume compiles contributions on geology, stratigraphy, taxonomy, and mammal association's analyses of the SCF along the RSC.
\end{abstract}

Key words. Santacrucian. Notohippidian. Fossil mammals. Taxonomy. Ameghino.

Resumen. ANTECEDENTES HISTÓRICOS PARA UNA REVISIÓN DE LA PALEONTOLOGÍA DE LA FORMACIÓN SANTA CRUZ (MIOCENO TEMPRANOMEDIO) A LO LARGO DEL RÍO SANTA CRUZ, PATAGONIA, ARGENTINA. En 1887, Carlos Ameghino realizó la primera expedición geológica y paleontológica al Río Santa Cruz (RSC), Patagonia, Argentina. Entre 1887 y 1889, Florentino Ameghino estudió los fósiles obtenidos por Carlos, con los que fundó más de 120 taxones y estableció su Formación Santacruceña y Piso Santacruceño. En 1888, F. Ameghino fue exonerado del Museo de La Plata y reemplazado por Alcides Mercerat en 1889, iniciándose una fuerte competencia por los fósiles santacrucenses. A partir de 1890 estos fueron recolectados principalmente en la costa atlántica. Hasta 1894 Ameghino y Mercerat fundaron más de 500 especies de mamíferos, $80 \%$ de las cuales le correspondían a Ameghino quien, posteriormente, sinonimizaría casi todas las especies de Mercerat. A fines del siglo XIX exploradores extranjeros recorrieron Patagonia, pero casi no recolectaron en el RSC. Así, las principales colecciones del río se realizaron hasta 1889. Las colecciones santacrucenses del siglo XIX poseen información geográfica vaga y hasta contradictoria. Así sucede con las especies del Santacrucense reasignadas por Ameghino al Notohippidense, asociación por él ubicada al noroeste del RSC. Análisis recientes evidencian que varios de esos ejemplares fueron recolectados al suroeste del RSC. Estas y otras evidencias prueban la inconveniencia de utilizar los datos de las viejas colecciones sin un análisis crítico de la historia de su procedencia. Desde 2003 se inició un programa de investigación que impulsó estudios bioestratigráficos y paleoecológicos en la Formación Santa Cruz (FSC). Este Volumen Temático reúne contribuciones sobre geología, estratigrafía, taxonomía y análisis de asociaciones de mamíferos de la FSC en el RSC.

Palabras clave. Santacrucense. Notohippidense. Mamíferos fósiles. Taxonomía. Ameghino. 
The Santa Cruz Formation (SCF) is an Early-Middle Miocene (Burdigalian-early Langhian) continental sedimentary succession within the Austral-Magallanes Basin widely distributed in southern Patagonia (Cuitiño et al. 2016, 2019), in the Province of Santa Cruz, Argentina (Fig. 1). It amalgamates historical and scientific values that strongly promoted and influenced the general approach to the study of continental vertebrate paleontology and stratigraphy of the Cenozoic of South America for over a century.

Particularly, the SCF along the Río Santa Cruz (RSC) was the first terrestrial unit of Patagonia formally and exhaustively explored from geologic and paleontological perspectives during the late $19^{\text {th }}$ century, despite Fitzroy and Darwin had walked past them in 1834. New kinds of fossil vertebrates recovered in the first expedition to the RSC by Carlos Ameghino resulted in a massive foundation of names of fossil vertebrates in South America (Ameghino, 1887), albeit weakly described, without illustrations and, in many cases, based on very fragmentary and/or poorly preserved specimens. These and many other taxa described in the following years served Florentino Ameghino as a reference collection for the comparisons with every new Cenozoic fauna of Patagonia recorded in the subsequent two decades (Ameghino, 1906). The SCF constituted Ameghino's Piso Santacruceño, and its fauna his étages notohippidéen and santacruzéen, which provided the basis for the foundation of the Santacrucian South American Land Mammal Age (SALMA; Pascual et al., 1965; Marshall et al., 1983). Ameghino also believed that many of the species he described were more ancient than what we now understand, and that he had documented the ancestors of many mammalian orders in South America, including those of artiodactyls, perissodactyls, and even human beings (Ameghino, 1891a, 1907). These claims prompted researchers from Europe and North America to undertake the study of Santacrucian fossils, either by organizing their own expeditions or getting specimens from Ameghino's collections (Vizcaíno et al., 2012a, 2013).

Simpson (1980) highlighted the importance of the Santacrucian as representative of a phase in South American mammal history in which the communities consisted of a complex mixture of descendants of ancient lineages of the continent (Marsupialia, Xenarthra, Litopterna, Notoungulata, and Astrapotheria) and new forms from other continents (Rodentia and Primates). This and the fact that some localities have provided excellently preserved fossils promoted paleobiological and paleoecological studies of this fauna. Vizcaíno et al. (2012b) and Kay et al. (2012) reviewed the published paleoecological contributions on the Santacrucian and performed their own studies based on Santacrucian localities from the Atlantic coast. One of their objectives was to provide a model to reconstruct the paleoecology of the SCF, especially the niche structure for a geographicallly and stratigraphically restricted sets of intensely collected localities, by identifying the number of species, and evaluating different biological parameters. Vizcaíno et al. (2012b) promoted future studies by which this approach could be applied to a more complete geographic and chronologic range of the SCF, recording different assemblages at different levels and evaluating ecological changes that occurred during the time of deposition of the unit in different areas.

This research program impelled, among other efforts, the initiation of geological and paleontological studies on the mostly forgotten outcrops of the SCF along the RSC, the area from where this unit was originally recognized and the first large fossil collection was first made. The project started with the relocation of the localities prospected in the $19^{\text {th }}$ century by Francisco P. Moreno and Carlos Ameghino (see below), mostly based on a field season in November 2009, reported by Fernicola et al. (2014) and dated by Cuitiño et al. (2016). Teams of 10-12 people undertook intensive field work during the succeeding Austral summers of 2013 and 2014 (Fig. 2). On average, they collected fossils for 20 days from the localities Barrancas Blancas, Segundas Barrancas Blancas and Yaten Huageno, situated along an approximately $100 \mathrm{~km}$ stretch of the RSC. Another factor that catalyzed the project was the imminent construction of dams on the RSC that will affect the accesses and the outcrops themselves, particularly in the localities Yaten Huageno (Condor Cliff dam) and Segundas Barrancas Blancas (La Barrancosa dam; Fig. 3) (https://www.minem.gob.ar/www/ 839/25793/represas-aprovechamientos-hidroelectricos-riosanta-cruz). The project then became a paleontological rescue. Virtually all identifiable pieces were collected without size or taxonomic bias, constituting more than 1900 specimens that now belong to the Museo Regional Provincial 


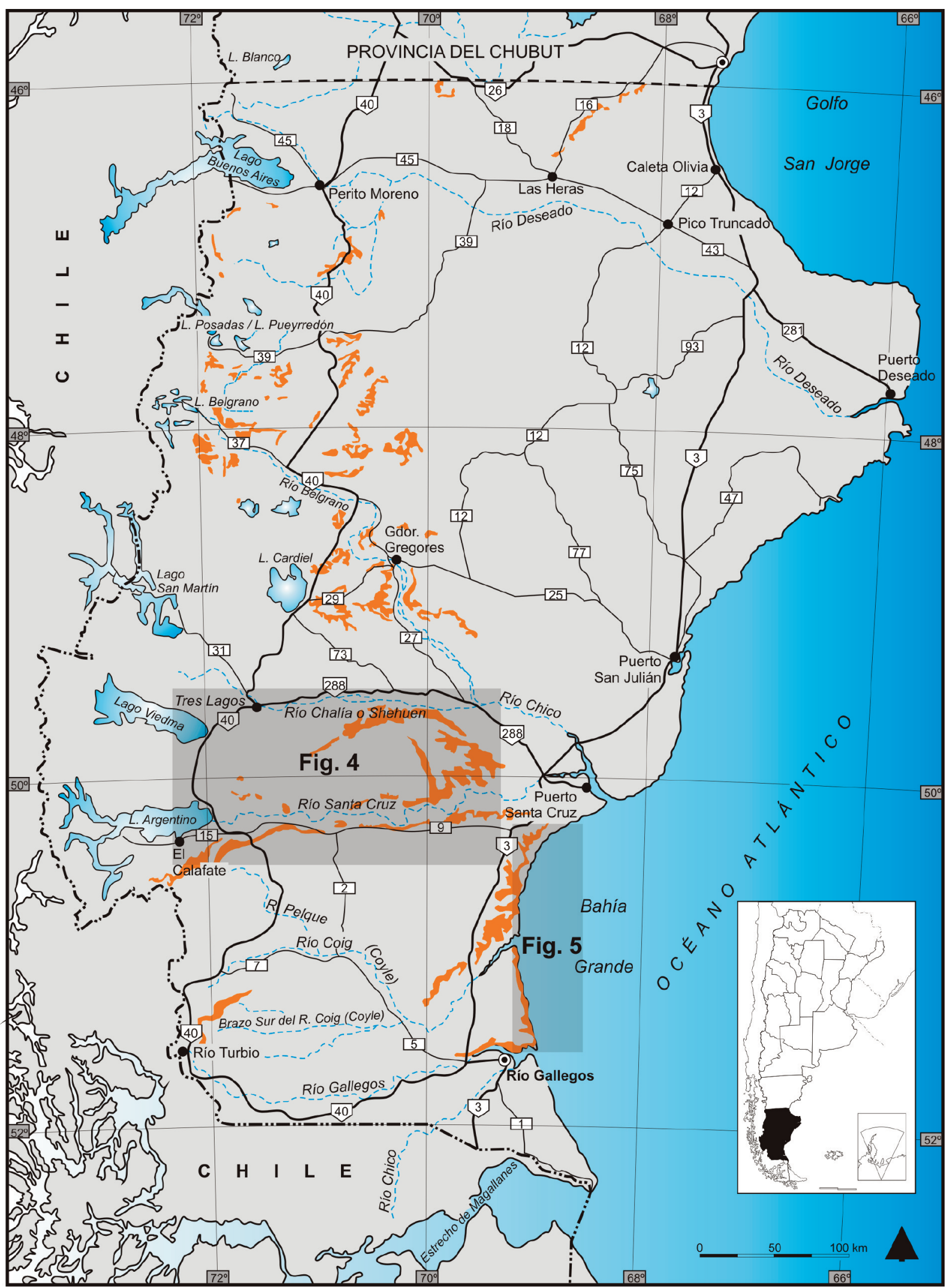

Figure 1. Map of the Province of Santa Cruz showing the distribution of the Santa Cruz Formation (in orange), and the study areas detailed in figures 4 and 5. 

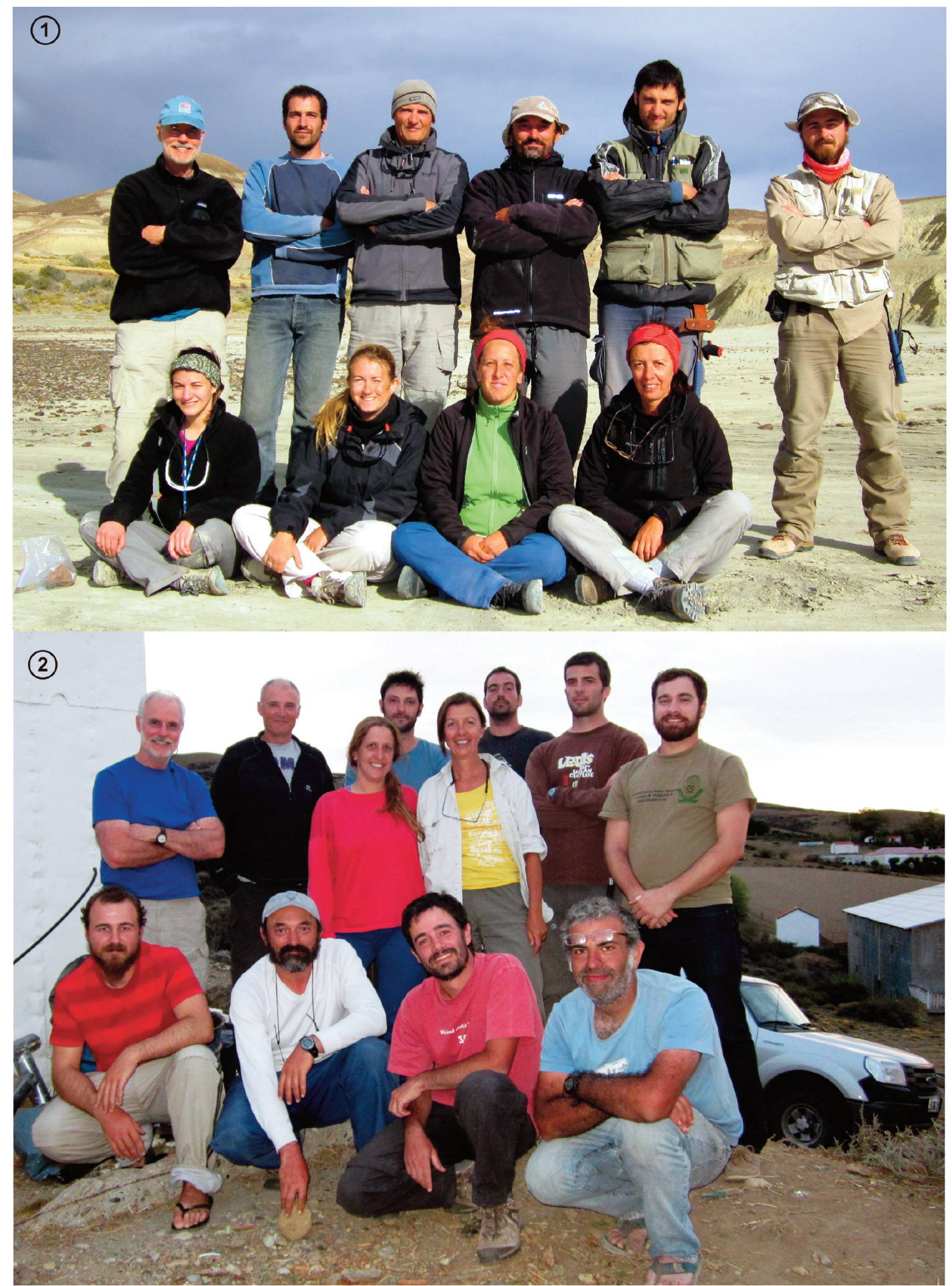

Figure 2. Field teams who worked during the summer seasons. 1, 2013: from left to right, back row R.F. Kay, S. Hernández del Pino, S.F. Vizcaíno, J.C. Fernicola, N. Toledo, and N.A. Muñoz; front row, L. González, V. Krapovickas, L. Chornogubsky, and M.S. Bargo; 2, 2014: from left to right, back row R.F. Kay, S.F. Vizcaíno, N. Toledo, S. Hernández del Pino, A. Racco, and J. Spradley; middle row, L. Chornogubsky and M.S. Bargo; front row N.A. Muñoz, J.C. Fernicola, J.I. Cuitiño, and L. Acosta. 
"Padre M. Jesús Molina" of Río Gallegos (Province of Santa Cruz, Argentina). The specimens were collected recording geographic coordinates, stratigraphic provenance, and/or altitude as precisely as possible.

The project included geologists who recorded stratigraphic profiles and established correlations among the different localities (Cuitiño et al., 2019), and were studied by specialists of the different taxa: invertebrates (Pérez et al., 2019), Anura (Muzzopapa, 2019), Aves (Diederle and Noriega, 2019), Metatheria (Chornogubsky et al., 2019), Rodentia (Arnal et al., 2019), Xenarthra Folivora (Bargo et al., 2019), Xenarthra Cingulata (Fernicola and Vizcaíno, 2019),

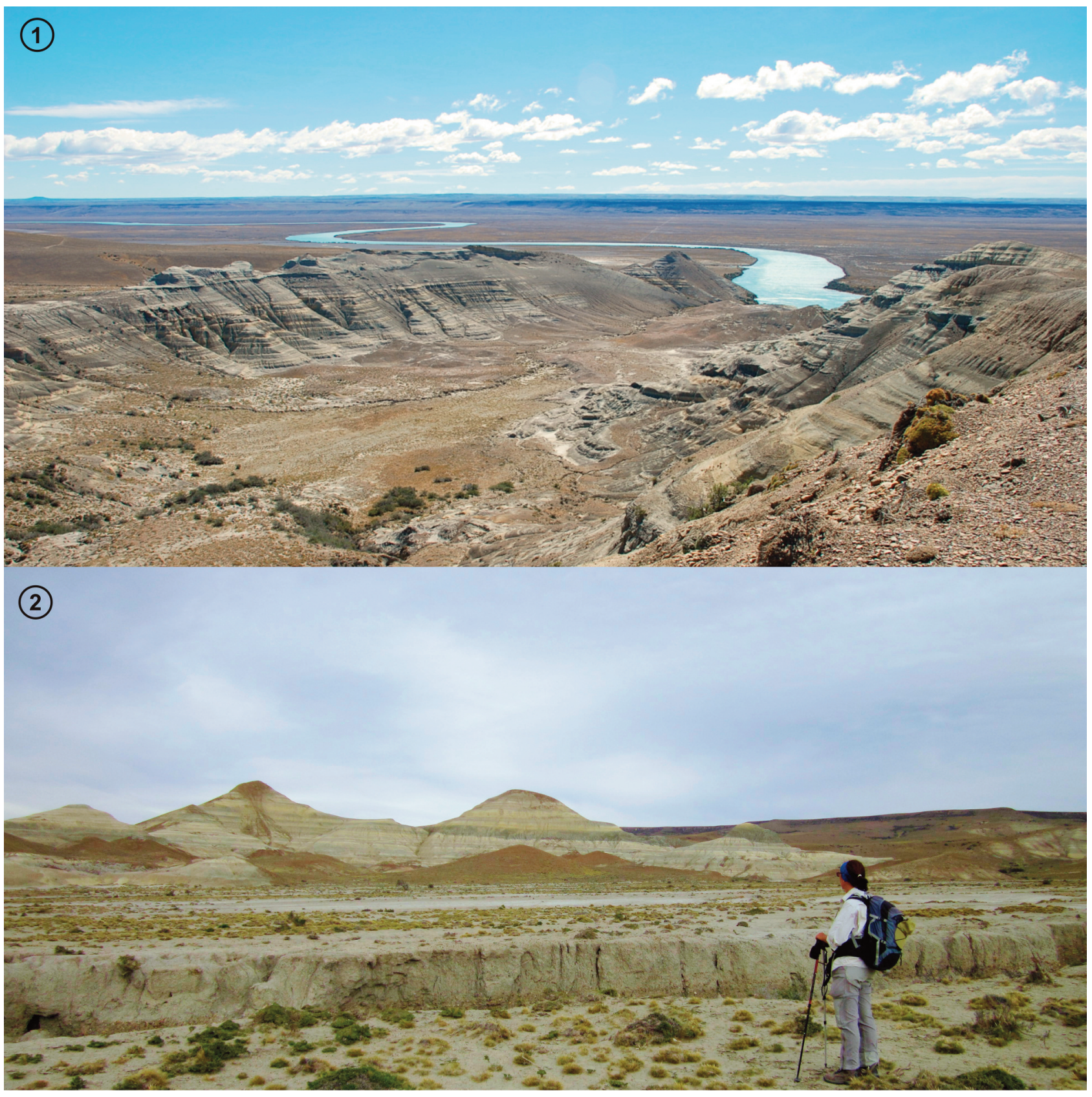

Figure 3. Exposures of the Santa Cruz Formation in the Río Santa Cruz at Segundas Barrancas Blancas locality. La Barrancosa dam will be located in this area. 1, Ea. Cordón Alto; 2, Ea. El Tordillo. 
Notoungulata and Astrapotheria (Fernández and Muñoz, 2019), Litopterna (Schmidt et al., 2019), and Primates (Kay and Perry, 2019). The results were compiled to undertake an analysis of the mammal associations recorded in the localities along the Río Santa Cruz (Fernicola et al., 2019).

The objective of this contribution is to analyze the historical evidence on how the collections and early publications on the SCF at the Río Santa Cruz, and its fossil vertebrate content, modeled and conditioned the interpretation of its value as temporal or biostratigraphic indicators. In doing so, we expect to provide an accurate, stratigraphically and geographically controlled data upon which to base future bioestratigraphic and paleoecological interpretations generated from the study of new fossil collections from the Río Santa Cruz as they occur.

\section{THE SANTA CRUZ FORMATION IN THE RÍO SANTA CRUZ}

Until the first decade of the $20^{\text {th }}$ century, the outcrops of the SCF at the RSC were referred to as discontinuous exposures located in the middle part of the river between Lago Argentino and Puerto Santa Cruz. Thus, Marshall (1976), taking as reference other authors, established that the fossiliferous unit was mainly located from 75 to $125 \mathrm{~km}$ east of Lago Argentino. Fernicola et al. (2014) were able to establish, from the study of Carlos Ameghino's field book of his 1887 expedition published by Rusconi (1965), the precise collection sites located on the right and left banks of the RSC. They found Carlos Ameghino's localities on the right margin to be, from east to west: Barrancas Blancas (Estancias Santa Lucía and Aguada Grande), Segundas Barrancas Blancas (Estancias Cordón Alto, El Tordillo y Rincón Grande) and Yaten Huageno (Estancia El Refugio). They also located a fourth locality on the Río Bote (Estancia María Elisa), a tributary of the RSC, located southeast of Lago Argentino (Fig. 4) hardly mentioned in Carlos' field notebook (in Rusconi, 1965). According to C. Ameghino (in Rusconi, 1965), on the left margin of the RSC there were three other fossiliferous localities, just in front of those on the right margin. So far, the left bank has not been further prospected.

\section{The fossils from the first paleontological expedition to the Río Santa Cruz}

In 1876-77, Francisco P. Moreno collected the first fossils from sediments referred to the SCF up the valley of the RSC during an expedition to Lago Argentino (Moreno, 1879). One of these specimens was published without Moreno's consent as the new species Astrapotherium patagonicum Burmeister, 1879 (Fernicola, 2011a,b). Beyond the fact that it unleashed an important conflict among these natu-

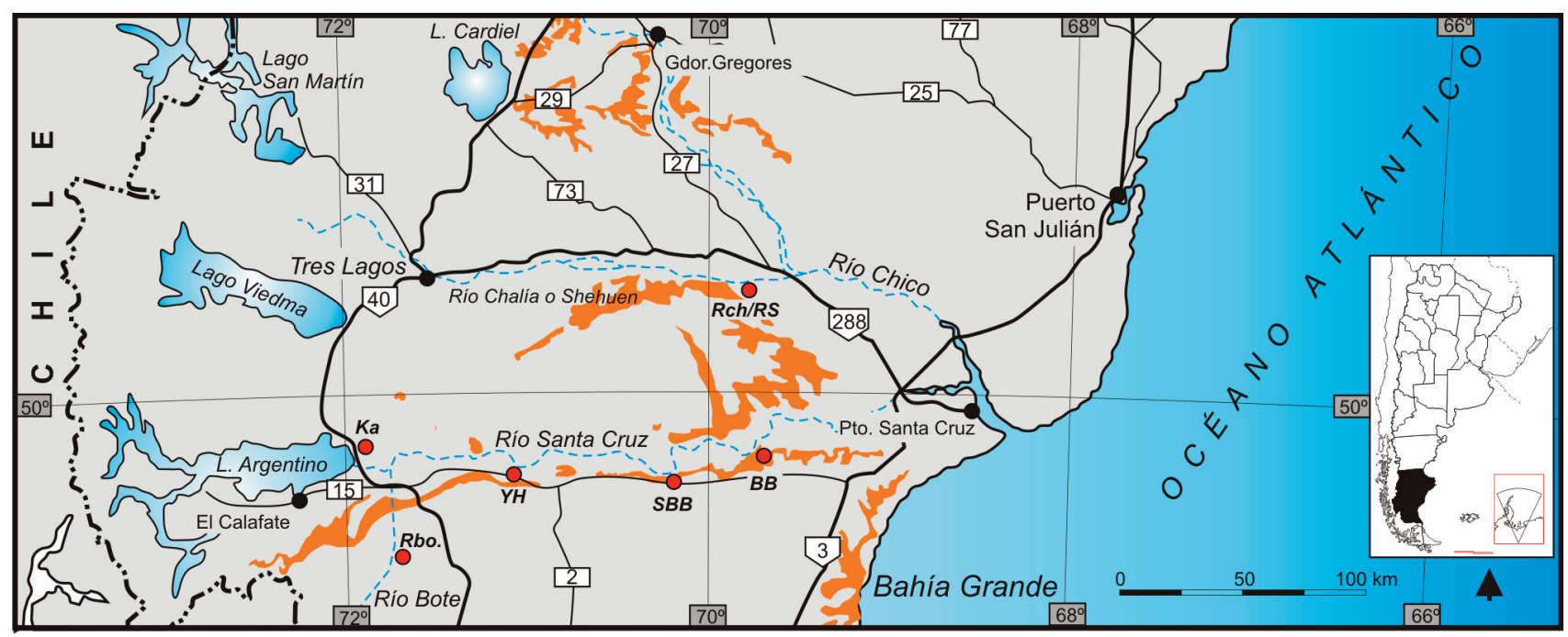

Figure 4. Fossil localities in the Río Santa Cruz, Río Chalía, and the western area in surroundings of Lago Argentino. BB, Barrancas Blancas; SBB, Segundas Barrancas Blancas, YH, Yaten Huageno; Rch/RS, Río Chalía (=Río Sehuen); Ka, Karaiken; Rbo, Río Bote. 
ralists, this taxon represents the first formal mention of the deposits of the RSC. Later, in a lecture focused on his Patagonian expedition of 1876-77, Moreno (1882) mentioned the existence of half a dozen new species but never published them formally. In 1885, Florentino Ameghino erected the species Pachyrukhos moyani Ameghino, 1885 on the basis of remains collected by Carlos María Moyano about 145 kilometers from the mouth of the RSC.

These circumstances, added to a growing paleontological confrontation (Fernicola, 2011a,b) between Hermann Burmeister, then Director of the Museo Público de Buenos Aires, and F.P. Moreno and F. Ameghino, Director and ViceDirector respectively of the Museo de La Plata. Moreno entrusted C. Ameghino to make a geological and paleontological prospection of the RSC outcrops. Carlos fulfilled the requested work in 1887 (Farro, 2008, 2009; Podgorny, 2009; Fernicola, 2011a,b; Vizcaíno, 2011; Vizcaíno et al., 2012a, 2013).

The expedition was supported by the Museo de La Plata. Carlos had all the field information that Moreno offered him, such as the complete map of the RSC that C.M. Moyano made with great detail during the 1876-77 expedition. The information provided by Moreno and his remarkable performance as a field naturalist allowed Carlos to return to Buenos Aires with more than 2000 fossil vertebrate specimens that were quickly described by his brother Florentino (Ameghino,1887). He recognized 122 taxa, of which 110 were new species, and indicated that more detailed descriptions of these new taxa were going to be published soon. At the beginning of 1888, Florentino was expelled by Moreno from the Museo de La Plata, but this fact did not prevent him from publishing more extensively on the 1887 collections two years later (Ameghino, 1889). This was possible because before leaving the institution he had already finished many of the descriptions, and also because he had retained for himself a considerable portion of the collection made by his brother in 1887 (Fernicola 2011a,b). Fifteen of the 19 new species that Ameghino described in 1889, and whose provenance was recognized by him as the "Piso santacruceño eoceno inferior" from the Santa Cruz terrritory, were based on specimens collected in 1887 by Carlos. According to what Florentino asserted (Ameghino 1889, p. $138,186,657)$, the remaining four species corresponded to specimens that Moyano gave him.

\section{Other early collections}

Between the years 1888 and 1984, the paleontological collections of the Museo de La Plata increased with new Santacrucian specimens from different localities of the RSC and the Atlantic coast, collected by other explorers of that institution (Vizcaíno et al., 2013; Brinkman and Vizcaíno, 2014). Many of these specimens together with those collected by Carlos in 1887 and housed in the Museo de La Plata were also studied by the Swiss geologist Alcides Mercerat, who superseded F. Ameghino as paleontologist of the Museo de La Plata in 1889. Mercerat (1891a-g) named more than 80 new taxa of vertebrates from Santa Cruz; unfortunately, none of them was figured. In 1892, Mercerat left the Museo de La Plata and abandoned his study of Santacrucian fossils.

When early in 1889 Carlos Ameghino returned from a trip to Chubut commissioned by Moreno, he knew he had been excluded from the Museo de La Plata, completing the definitive rupture between the Ameghino brothers and Moreno after the exoneration of Florentino in 1888 (Fernicola, $2011 a, b)$. Both events affected the study of the SCF. On the one hand, as already mentioned, Florentino retained part of the material of 1887 deposited in the Museo de La Plata. On the other hand, the situation forced Carlos to work in Patagonia without institutional affiliation, but not necessarily without official support (Vizcaíno, 2011; Vizcaíno et al., 2013). Carlos continued doing fieldwork in Patagonia until 1903.

In relation to the outcrops of the Piso Santacruceño, in 1889 Carlos crossed the left bank of the RSC reaching the area of Karaiken; in 1890 he stayed in the central area of the Santa Cruz territory, collecting specimens in the Río Chalía (= Sehuen), and from 1890 to 1893 he explored and recovered a large number of specimens along the Atlantic coast between Monte León to Cabo buen Tiempo and along the Río Gallegos (Fig. 5). As soon as the fossils arrived to La Plata from Patagonia, Florentino studied them increasing considerably the species number of fossil vertebrates (Ameghino, 1890, 1891a-c, 1894a).

Between 1890 and 1895, there was a complex dispute concerning the taxonomy of Santacrucian fauna with two taxonomic proposals, the ones by Ameghino and Mercerat, which considerably increased the number of taxa. Ameghino 


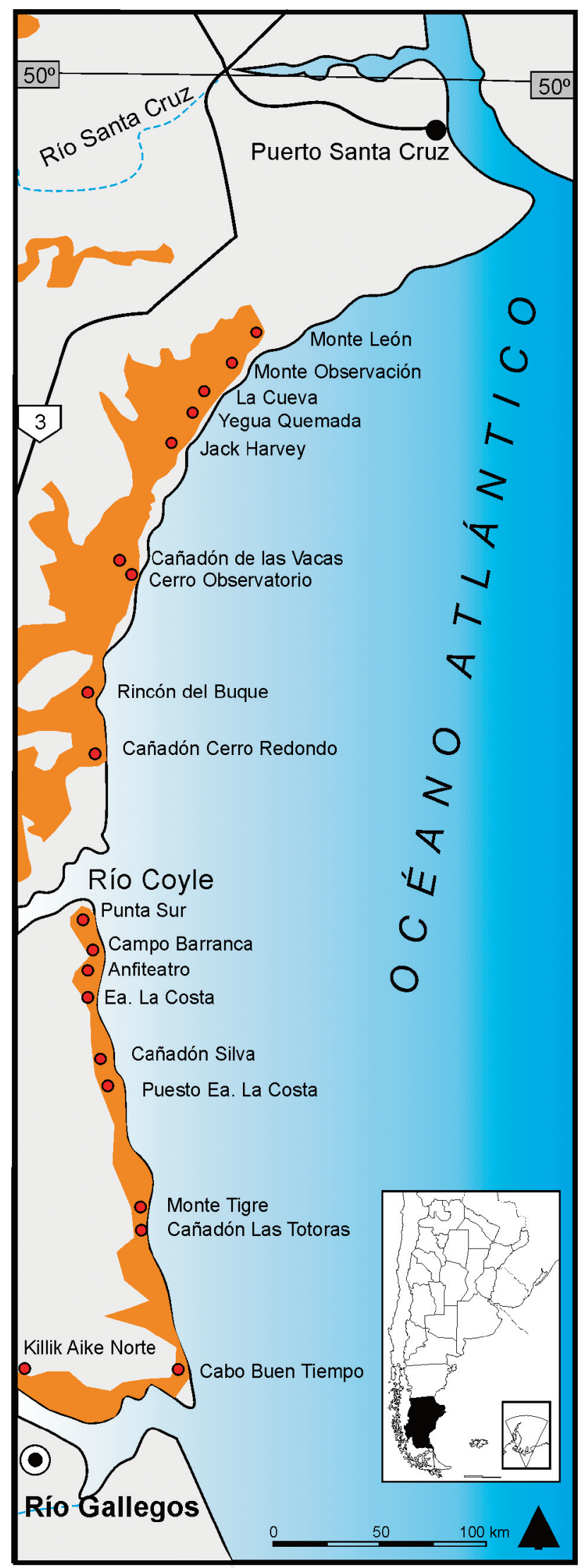

(1894a) presented his taxonomic synthesis in which he recognized about 300 terrestrial vertebrate Santacrucian taxa in which practically all the taxa founded by Mercerat (1891a-g) were synonymized. This is remarkable because he could not have seen Mercerat's specimens as he was not authorized to visit the collections of the Museo de La Plata (Ameghino, 1889; Fernicola, 2011a).

In the meantime, in 1893, the English paleontologist Richard Lydekker arrived at the Museo de La Plata invited by Moreno (Lydekker, 1894a) to study the paleontological vertebrate collection, including all the museum's Santacrucian specimens. Lydekker spent nearly three months studying the specimens, and published his own taxonomic proposals (Lydekker, 1894a,b). Unlike those previously proposed by Mercerat and Ameghino, he significantly reduced the number of recognized species. As occurred with Mercerat's proposal, Ameghino (1894b, 1895) quickly replied and completely rejected Lydekker's taxonomic arrangement. In this extremely complex context in which none of the naturalists could study the complete collections, the taxonomic proposal that passed to the $20^{\text {th }}$ century was basically that of Ameghino (1894a).

The remarkable interest regarding this fauna promoted several foreign institutions to send expeditions to Patagonia in the succeeding three decades (Vizcaíno et al., 2013, 2016). The most outstanding were conducted between 1886 and 1889 by John B. Hatcher (Princeton University, USA), as part of a research initiative of Professor William B. Scott of Princeton University. Hatcher visited different locations in Santa Cruz Territory, mostly on the Atlantic coast, and spent short time along the RSC (Hatcher, 1903, p. 113). While organizing a series of monographs on the Princeton Expeditions to Patagonia, Scott visited Argentina in 1902 to study and photograph the type materials and Santacrucian specimens in the Museo de La Plata, in the museum in Buenos Aires, and the private collection of Florentino Ameghino. The

Figure 5. Detailed map of the localities in the coastal Santa Cruz Formation, between Monte León and Río Gallegos. These localities have been explored and studied, since 2003 to present, as part of our research program. 
album of photographs taken by Scott was rediscovered by Vizcaíno et al. (2017). These studies allowed him to carry out an extensive revision of Ameghino's taxonomic arrangement. In a series of lavishly illustrated monographs published between 1903 and 1912 by the Princeton University, every taxonomic group represented in the SCF was reviewed, in general greatly reducing the number of taxa (e.g., Scott, 1903, 1904; Sinclair, 1906, 1909). The new taxonomic proposals such as that of the Xenarthra (Scott, 1903, 1904) were not considered by Ameghino, who continued using his own taxonomic arrangement (Ameghino, 1906) until his death in 1911. In the end, both local and international scientific communities came to adopt, albeit with modifications, the taxonomic proposals published in the Reports of the Princeton University Expeditions to Patagonia between 1901 and 1912.

\section{The Santacrucian/Notohippidian issue}

As mentioned above, the great diversity of vertebrates recognized by Ameghino between 1887 and 1889 on specimens recovered from the RSC and other areas (such as Río Chico and Río Gallegos), led Ameghino (1889) to propose a new faunal association that characterized his Piso Santacruceño. Almost 90\% of the taxa included in this association were founded on specimens from Carlos' 1887 expedition. By 1900, the number of species recognized in the Santacrucian Stage by Ameghino (1894a) was about 400. Unfortunately, the information of the specimens on which the Santacrucian Stage was founded is scarce. Neither the publications of Ameghino nor those of Mercerat, included precise stratigraphic provenance of the specimens; and only in few cases, did they cite a geographic location (see below). In the collection made by C. Ameghino in 1887, he refers only to the Barrancas del Río Santa Cruz (Ameghino, 1889), without indicating a specific locality (i.e., Barrancas Blancas, Segundas Barrancas Blancas or Yaten Huageno) where each specimen came from. This information is neither available in the catalogs of the Museo de La Plata and the Ameghino Collection in the Museo de Buenos Aires.

Ameghino (1900-1902, 1906) subdivided his Piso Santacruceño into the older notohippidéen and the younger santacruzéen étages. In doing so, he listed 72 species for the Notohippidian, 54 of which he considered exclusive of this stage. According to Ameghino (1900-1902, 1906) the specimens on which he based the Notohippidian had been collected by Carlos Ameghino in 1889, from outcrops restricted to a small region in Karaiken, north of the RSC, about $20 \mathrm{~km}$ northeast of Lago Argentino (see Ameghino, 1906, fig. 57).

Fernicola et al. (2014) provided evidence that some of the specimens included by F. Ameghino in the Notohippidian had been collected by C. Ameghino in 1887, not in 1889. According to these authors, 38 of the supposedly 54 exclusive Notohippidian species listed by Ameghino (19001902), were erected by F. Ameghino after 1890, whereas of the remaining 16, 10 were founded by F. Ameghino in 1887 and six in 1889. Furthermore, the specimens of 15 of the 16 species erected before 1889 had been collected by C. Ameghino in 1887.

This implies that the specimens of those 15 species could not have been collected at Karaiken but must come from some locality samples of the 1887 expedition. Fernicola et al. (2014) proposed that the specimens of those 15 Notohippidian species were collected by Carlos from rocks cropping out by the Río Bote about $25 \mathrm{~km}$ southeast of Lago Argentino. As a consequence, the geographic distribution of the Notohippidian recognized by Ameghino (1900-1902, 1906) would not be restricted to Karaiken locality, but also near Lago Argentino south of the RSC, including Río Bote and probably other outcrops nearby. Furthermore, in the Ameghino's catalog there are specimens collected in different localities along the Atlantic coast, identified as exclusive species of the Notohippidian listed by Ameghino (19001902) (Fernicola, pers. obs. 2018). Consequently, it becomes difficult to establish the actual distribution of many species of the RSC involved in Ameghino's distinction between the Santacrucian and Notohippidian stages.

\section{FINAL REMARKS}

The complex dispute between paleontologists and institutions occurred during the last 25 years of the $19^{\text {th }}$ century seriously affected the paleontological studies of the SCF during that period. For instance, many of the new species were founded on very fragmentary and/or poorly preserved specimens, poorly described and not figured. Furthermore, most of those specimens do not have original labels indicating their status as types. All these facts implies the 
need of comprehensive taxonomic revisions of the SCF taxa, carefully reviewing the descriptions by Ameghino (1887, 1889, 1890, 1891a-c, 1894a,b), Mercerat (1891a-g), Lydekker (1894a,b), and Princeton's monographs. But also meticulously searching the location of holotype or syntype specimens and eventually, in the absence of them, the nomination of neotypes. Several Doctoral Dissertations have been conducted in the last decade to solve these problems, such as that on the Cingulata by González Ruiz (2010) and Toxodontia by Hernández del Pino (2017), and others are nearly complete, as is the case of Typotheria and Folivora.

Also, most of the specimens recorded in the historical collections of the museums of La Plata and Buenos Aires lack of precise geographic and stratigraphic information, while those in the Princeton collection (now in Yale Peabody Museum, USA) have the former, but lack the latter. Certainly, biostratigraphic and paleoecological studies require this information, unless it can be established that the levels studied do not differ temporarily from one another.

Recent radiometric dates provide a new chronological scheme for the SCF, including the Atlantic coastal (Fleagle et al., 2012; Perkins et al., 2012; Trayler et al., 2019) and in the RSC (Cuitiño et al., 2016) localities dealt with in this contribution. The latter proposes that the sedimentary sequences in Barrancas Blancas ( 17.45 to $\sim 16.49 \mathrm{Ma}$ ) and Yaten Huageno ( 17.22 to $\sim 16.67 \mathrm{Ma})$ are older than those at Segundas Barrancas Blancas ( 16.32 to $15.63 \mathrm{Ma}$ ). Moreover, the time span of the fossiliferous levels of Barrancas Blancas and Yaten Huageno indicates that the associated faunal assemblage is synchronous with and younger in part than the faunal assemblages of the eastern coastal localities, from Monte León to Killik Aike Norte ( 17.85 to 16.20 Ma). Segundas Barrancas Blancas is partially synchronous and younger than the faunal assemblages from Monte León to Cerro Observatorio ( 17.85 to $\sim 16.20 \mathrm{Ma}$ ). Interestingly, the higher levels of Segundas Barrancas Blancas overlap chronologically with the Collon Curá Formation from the Province of Río Negro in northern Patagonia, which bears a Colloncuran fauna (Vucetich et al., 1993; González Ruiz et al., 2013).

The absence of precise geographic and stratigraphic in- formation in the old collections, as well as the doubts about the reliability of Ameghino's catalogs regarding the provenance of several Notohippidian species, prevent us from considering Ameghino's references in new biostratigraphic and paleoecological studies of the RSC and reinforced the need to perform our own large-scale field work and collections.

In the following articles of this thematic volume, we compiled a contribution on the stratigraphy of the Santa Cruz Formation on the right banks of the Río Santa Cruz, and an update of the record and systematics of their fossil vertebrates, based on the new collections made during the 2013-2014 fieldworks of our research program. The last article of this volume analyses the associations of mammals of the Santa Cruz Formation along the Río Santa Cruz. This new evidence constitutes the starting point for further comparisons with others Santacrucian exposures in Patagonia.

\section{ACKNOWLEDGEMENTS}

We thank the collection managers of the Vertebrate Paleontology collections at MLP (M. Reguero), and MACN (L. Chornogubsky and M. Ezcurra), and the Dirección de Patrimonio, Secretaría de Cultura de Estado, and Museo Regional Provincial P.M.J. Molina (Río Gallegos, Province of Santa Cruz). We thank especially L. Acosta, L. Chornogubsky. J. Cuitiño, L. González, S. Hernández del Pino, V. Krapovickas, N. Muñoz, J. Spradley, N. Toledo, and A. Racco for their collaboration during the field work. Also, we acknowledge people form the Estancias along the Río Santa Cruz and Río Bote who gave us access to the outcrops and or provided camp spaces (Estancias El Vapor, Cordón Alto, Aguada Grande, Santa Lucía and María Elisa). We thank the reviewers M.G. Vucetich and M. Bond for their comments and suggestions. This is a contribution to the projects PIPCONICET 00781 (JCF), UNLP 11/N867, PICT 2013-0389 (SFV.), PICT 2017-1081 (MSB), National Science Foundation 0851272 and 1348259, and National Geographic Society 9167-12 (RFK).

\section{REFERENCES}

Ameghino, F. 1887. Enumeración sistemática de las especies de mamíferos fósiles coleccionados por Carlos Ameghino en los terrenos eocenos de Patagonia Austral y depositados en el Museo de La Plata. Boletín del Museo de La Plata 1: 1-26.

Ameghino, F. 1889. Contribución al conocimiento de los mamíferos fósiles de la República Argentina. Actas de la Academia Nacional de Ciencias 6: 1-1027.

Ameghino, F. 1890. Los Plagiaulacídeos argentinos y sus relaciones zoológicas, geológicas y geográficas. Boletín del Instituto Geográfico Argentino 11: 143-201.

Ameghino, F. 1891a. Caracteres diagnósticos de cincuenta especies nuevas de mamíferos fósiles argentinos. Revista Argentina de Historia Natural 1: 129-167.

Ameghino, F. 1891b. Nuevos restos de mamíferos fósiles descubiertos por Carlos Ameghino en el Eoceno inferior de la Patagonia austral. Especies nuevas, adiciones y correcciones. Revista 
Argentina de Historia Natural 1: 289-328.

Ameghino, F. 1891c. Observaciones críticas sobre los mamíferos eocenos de la Patagonia austral. Revista Argentina de Historia Natural 1: 328-382.

Ameghino, F. 1894a. Énumération synoptique des espèces de mammifères fossiles des formations éocènes de Patagonie. Boletín de la Academia Nacional de Ciencias de Córdoba 13: 259455.

Ameghino, F. 1894b. Sur les ongulés fossiles de l'Argentine (Examen critique de l'ouvrage de R. Lydekker: A study on the extinct ungulates of Argentina. Revista del Jardín Zoológico de Buenos Aires 2: 193-224; 225-256; 257-288; 289-303.

Ameghino, F. 1895. Sur les édentés fossiles de l'Argentine: Examen critique, revision et correction de l'ouvrage de R. Lydekker: The extinct edentates of Argentina. Revista del Jardín Zoológico de Buenos Aires 3: 97-192.

Ameghino, F. 1900-1902. L'âge des formations sédimentaires de Patagonie. Anales de la Sociedad Cientifica Argentina 50: 109130, 145-165, 209-229; 51: 20-39; 52: 65-91, 189-197, 244-250; 54: 161-180, 220-249, 283-342.

Ameghino, F. 1906. Les formations sédimentaires du Crétacé Superieur et du Tertaire de Patagonie avec un parallele entre leurs faunes mammalogiques et celles de l'ancien continent. Anales del Museo Nacional de Buenos Aires 15:1-568.

Ameghino, F. 1907. Notas preliminares sobre el Tetraprothomo argentinus: un precursor del hombre del Mioceno superior de Monte Hermoso. Anales del Museo Nacional de Buenos Aires 9: 107-242.

Arnal, M., Pérez, M.E., and Deschamps, C.M. 2019. Revision of the Miocene Caviomorph rodents from the Río Santa Cruz (Argentinean Patagonia). In: J.C. Fernicola, M.S. Bargo, S.F. Vizcaíno, and R.F. Kay (Eds.), Early-Middle Miocene Paleontology in the Río Santa Cruz, Southern Patagonia, Argentina. 130 years since Ameghino, 1887. Publicación Electrónica de la Asociación Paleontológica Argentina 19: 193-229.

Bargo, M.S., De luliis R., and Toledo, N. 2019. Early Miocene sloths (Xenarthra, Folivora) from the Río Santa Cruz valley (Southern Patagonia, Argentina). Ameghino, 1887 revisited. In: J.C. Fernicola, M.S. Bargo, S.F. Vizcaíno, and R.F. Kay (Eds.), Early-Middle Miocene Paleontology in the Río Santa Cruz, Southern Patagonia, Argentina. 130 years since Ameghino, 1887. Publicación Electrónica de la Asociación Paleontológica Argentina 19: 102-137.

Brinkman, P.D., and Vizcaíno, S.F. 2014. Clemente Onelli's sketch map and his first-hand, retrospective account of an early fossil hunting expedition along the Río Santa Cruz, Southern Patagonia, 18881889. Archives of Natural History 41: 326-337.

Burmeister, G. 1879. Description physique de la République Argentine. D'après des observations personnelles et étrangères. Imprenta Paul-Émile Coni, Buenos Aires, 553 p.

Cuitiño, J.I., Fernicola, J.C., Kohn, M., Trayler, R., Naipauer, M., Bargo, M.S., Kay, R.F., and Vizcaíno, S.F. 2016. U-Pb geochronology of the Santa Cruz Formation (early Miocene) at the Río Bote and Río Santa Cruz (southernmost Patagonia, Argentina): implications for the correlation of fossil vertebrate localities. Journal of South America Earth Sciences 70: 198-210.

Cuitiño, J.I., Fernicola, J.C., Raigemborn, M.S., and Krapovickas, V. 2019. Stratigraphy and depositional environments of the Santa Cruz Formation (Early-Middle Miocene) along the Río Santa Cruz, Southern Patagonia, Argentina. In: J.C. Fernicola, M.S. Bargo, S.F. Vizcaíno, and R.F. Kay (Eds.), Early-Middle Miocene Paleontology in the Río Santa Cruz, Southern Patagonia, Argentina. 130 years since Ameghino, 1887. Publicación Electrónica de la Aso- ciación Paleontológica Argentina 19: 14-33.

Chornogubsky, L., Abello, M.A., and Barmak, G. 2019. The Metatheria from the Río Santa Cruz (Santa Cruz Formation, Early-Middle Miocene, Argentina): history and new findings. In: J.C. Fernicola, M.S. Bargo, S.F. Vizcaíno, and R.F. Kay (Eds.), Early-Middle Miocene Paleontology in the Río Santa Cruz, Southern Patagonia, Argentina. 130 years since Ameghino, 1887. Publicación Electrónica de la Asociación Paleontológica Argentina 19: 62-84.

Diederle, J.M., and Noriega, J.I. 2019. New records of birds from the Santa Cruz Formation (Early-Middle Miocene) at the Río Santa Cruz valley, Patagonia, Argentina. In: J.C. Fernicola, M.S. Bargo, S.F. Vizcaíno, and R.F. Kay (Eds.), Early-Middle Miocene Paleontology in the Río Santa Cruz, Southern Patagonia, Argentina. 130 years since Ameghino, 1887. Publicación Electrónica de la Asociación Paleontológica Argentina 19: 55-61.

Farro, M.E. 2008. [Historia de las colecciones en el Museo de La Plata, 1884-1906: naturalistas viajeros, coleccionistas y comerciantes de objetos de historia natural a fines del Siglo XIX. PhD Thesis, Facultad de Ciencias Naturales y Museo, Universidad Nacional de La Plata, La Plata, 550 p. Unpublished.].

Farro, M.E. 2009. La formación del Museo de La Plata. Coleccionistas, comerciantes, estudiosos y naturalistas a fines del siglo XIX. Prohistoria Ediciones, Rosario, $234 \mathrm{p}$.

Fernández, M., and Muñoz, N.A. 2019. Notoungulata and Astrapotheria (Mammalia, Meridiungulata) of the Santa Cruz Formation (EarlyMiddle Miocene) along the Río Santa Cruz, Argentine Patagonia. In: J.C. Fernicola, M.S. Bargo, S.F. Vizcaíno, and R.F. Kay (Eds.), Early-Middle Miocene Paleontology in the Río Santa Cruz, Southern Patagonia, Argentina. 130 years since Ameghino, 1887. Publicación Electrónica de la Asociación Paleontológica Argentina 19: 138-169.

Fernicola, J.C. 2011a. 1886-1888: Ascenso, auge y caída de la sociedad entre Florentino Ameghino y Francisco P. Moreno. Publicación Especial de la Asociación Paleontológica Argentina 12: 35-49.

Fernicola, J.C. 2011b. Implicancias del conflicto Ameghino-Moreno sobre la colección de mamíferos fósiles realizada por Carlos Ameghino en su primera exploración al río Santa Cruz, Argentina. Revista del Museo Argentino de Ciencias Naturales, n.s. 13: 41-57.

Fernicola, J.C., Cuitiño, J.I., Vizcaíno, S.F., Bargo, M.S., and Kay, R.F. 2014. Fossil localities of the Santa Cruz Formation (early Miocene, Patagonia, Argentina) prospected by Carlos Ameghino in 1887 revisited and the location of the Notohippidian. Journal of South America Earth Sciences 52: 9-107.

Fernicola, J.C., and Vizcaíno, S.F. 2019. Cingulates (Mammalia, Xenarthra) of the Santa Cruz Formation (Early-Middle Miocene) from the Río Santa Cruz, Argentine Patagonia. In: J.C. Fernicola, M.S. Bargo, S.F. Vizcaíno, and R.F. Kay (Eds.), Early-Middle Miocene Paleontology in the Río Santa Cruz, Southern Patagonia, Argentina. 130 years since Ameghino, 1887. Publicación Electrónica de la Asociación Paleontológica Argentina 19: 85-101.

Fernicola, J.C., Vizcaíno, S.F., Bargo, M.S., Kay, R.F., and Cuitiño, J.I. 2019. Analysis of the Early-Middle Miocene mammal associations at the Río Santa Cruz (Patagonia, Argentina). In: J.C. Fernicola, M.S. Bargo, S.F. Vizcaíno, and R.F. Kay (Eds.), Early-Middle Miocene Paleontology in the Río Santa Cruz, Southern Patagonia, Argentina. 130 years since Ameghino, 1887. Publicación Electrónica de la Asociación Paleontológica Argentina 19: 239-259.

Fleagle, J.H., Perkins, M.E., Heizler, M.T., Nash, B., Bown, T.M., Tauber, A.A., Dozo, M.T., and Tejedor, M.F. 2012. Absolute and relative ages of fossil localities in the Santa Cruz and Pinturas Formations. In: S.F. Vizcaíno, R.F. Kay, and M.S. Bargo (Eds.), Early Miocene Paleobiology in Patagonia: high-latitude paleocommunities of the Santa Cruz Formation. Cambridge University Press, Cambridge, 
p. 41-58.

González Ruiz, L.R. 2010. [Los Cingulata (Mammalia, Xenarthra) del Mioceno temprano y medio de Patagonia (edades Santacrucense y "Friasense") revisión sistemática y consideraciones bioestratigráficas. Phd Thesis, Facultad de Ciencias Naturales y Museo, Universidad Nacional de La Plata, La Plata, 471 p. Unpublished.].

González Ruiz, L.R., Góis, F., Ciancio, M.R., and Scillato-Yané, G.J. 2013. Los Peltephilidae (Mammalia, Xenarthra) de la Formación Collón Curá (Colloncurense, Mioceno medio), Argentina. Revista Brasileira de Paleontologia 16: 319-330.

Hatcher, J.B. 1903. Narrative of the expedition. In: W.B. Scott (Ed.), Reports of the Princeton University Expeditions to Patagonia, 18961899. Vol. 1, Princeton University Press, Princeton, p. 1-296.

Hernández Del Pino, S. 2018. [Anatomía y sistemática de los Toxodontidae (Notoungulata) de la Formación Santa Cruz, Mioceno temprano, Argentina. PhD Thesis, Facultad de Ciencias Naturales y Museo, Universidad Nacional de La Plata, La Plata, 432 p. Unpublished.].

Kay, R.F., Vizcaíno, S.F., and Bargo, M.S. 2012. A review of the paleoenvironment and paleoecology of the Miocene Santa Cruz Formation. In: S.F. Vizcaíno, R.F. Kay, and M.S. Bargo (Eds.), Early Miocene Paleobiology in Patagonia: High-Latitude Paleocommunities of the Santa Cruz Formation. Cambridge University Press, Cambridge, p. 331-365.

Kay, R.F., and Perry, J.M.G. 2019. New primates the Río Santa Cruz and Río Bote (Early-Middle Miocene), Santa Cruz Province, Argentina. In: J.C. Fernicola, M.S. Bargo, S.F. Vizcaíno, and R.F. Kay (Eds.), Early-Middle Miocene Paleontology in the Río Santa Cruz, Southern Patagonia, Argentina. 130 years since Ameghino, 1887. Publicación Electrónica de la Asociación Paleontológica Argentina 19: 230-238.

Lydekker, R. 1894a. Contribuciones al conocimiento de los vertebrados fósiles de la Argentina. Part I. Anales del Museo de La Plata, Paleontología Argentina 1: 1-83.

Lydekker, R. 1894b. Contribuciones al conocimiento de los vertebrados fósiles de la Argentina. Part II. Anales del Museo de La Plata, Paleontología Argentina 2: 1-248.

Marshall, L.G. 1976. Fossil localities for Santacrucian (Early Miocene) mammals, Santa Cruz Province, Southern Patagonia, Argentina. Journal of Paleontology 50: 1129-1142.

Marshall, L.G., Hoffstetter, R., and Pascual, R. 1983. Mammals and stratigraphy: Geochronology of the continental mammal-bearing Tertiary of South America. Paleovertebrata, Mémoire Extraordinaire 1-93.

Mercerat, A. 1891a. Sinopsis de la familia de los Astrapotheridae (Eoceno de Patagonia). Revista del Museo de La Plata 1: 241-255.

Mercerat, A. 1891b. Sinopsis de la familia de los Protoxodontidae conservados en el Museo de La Plata (Eoceno de Patagonia). Revista del Museo de La Plata 1: 381-444.

Mercerat, A. 1891c. Sinopsis de la familia Bunodontheridae (Eoceno de Patagonia) conservados en el Museo de La Plata. Revista del Museo de La Plata 1: 447-471.

Mercerat, A. 1891d. Datos sobre restos de mamíferos fósiles pertenecientes a los Bruta conservados en el Museo de La Plata y procedentes de los terrenos eocenos de Patagonia. Revista del Museo de La Plata 2: 1-46.

Mercerat, A. 1891e. Caracteres diagnósticos de algunas especies del gen. Theosodon conservadas en el Museo de La Plata. Revista del Museo de La Plata 2: 47-49.

Mercerat, A. 1891f. Caracteres diagnósticos de algunas especies de Creodonta conservadas en el Museo de La Plata. Revista del Museo de La Plata 2: 51-56.
Mercerat, A. 1891g. Sobre la presencia de restos de monos en el eoceno de Patagonia. Revista del Museo de La Plata 2: 73-74.

Moreno, F.P. 1879. Viaje a la Patagonia Austral, emprendido bajo los auspicios del gobierno nacional, 1876-1877. Imprenta de La Nación, Buenos Aires, Argentina, 460 p.

Moreno, F.P. 1882. Patagonia, resto de un antiguo continente hoy sumergido. Contribuciones al estudio de las colecciones del Museo Antropológico y Arqueológico de Buenos Aires. Anales de la Sociedad Científica Argentina 14: 97-131.

Muzzopapa, P. 2019. Calyptocephalella (Anura, Australobatrachia) remains from the Río Santa Cruz (Early-Middle Miocene, Santa Cruz Formation), Santa Cruz Province, Argentina. In: J.C. Fernicola, M.S. Bargo, S.F. Vizcaíno, and R.F. Kay (Eds.), Early-Middle Miocene Paleontology in the Río Santa Cruz, Southern Patagonia, Argentina. 130 years since Ameghino, 1887. Publicación Electrónica de la Asociación Paleontológica Argentina 19: 48-54.

Pascual, R., Ortega Hinojosa, E.J., Gondar, D., and Tonni, E.P. 1965. Las edades del Cenozoico mamalífero de la Argentina, con especial atención a aquellas del territorio Bonaerense. Anales de la Comisión de Investigaciones Científicas 6: 165-193.

Pérez, L.M., Cuitiño, J.I., Varela, A.N., and Muñoz, N.A. 2019. Diplodon cf. colhuapiensis (Bivalvia, Hyriidae) in Santa Cruz Formation (Early-Middle Miocene), at the Río Santa Cruz, Patagonia, Argentina. Stratigraphic and paleoenvironmental considerations. In: J.C. Fernicola, M.S. Bargo, S.F. Vizcaíno, and R.F. Kay (Eds.), Early-Middle Miocene Paleontology in the Río Santa Cruz, Southern Patagonia, Argentina. 130 years since Ameghino, 1887. Publicación Electrónica de la Asociación Paleontológica Argentina 19: 34-47.

Perkins, M.E., Fleagle, J.G., Heizler, M.T., Nash, B., Bown, T.M., Tauber, A.A., and Dozo, M.T. 2012. Tephrochronology of the Miocene Santa Cruz and Pinturas Formations, Argentina. In: S.F. Vizcaino, R.F. Kay, and M.S. Bargo (Eds.), Early Miocene Paleobiology in Patagonia: High-Latitude Paleocommunities of the Santa Cruz Formation. Cambridge University Press, Cambridge, p. 23-40.

Podgorny, I. 2009. El sendero del tiempo y de las causas accidentales. Los espacios de la prehistoria en la Argentina, 1850-1910. Prohistoria Ediciones, Rosario, $331 \mathrm{p}$.

Rusconi, C. 1965. Carlos Ameghino. Rasgos de su vida y obra. Revista del Museo de Historia Natural de Mendoza 17: 1-160.

Schmidt, G.I., Hernández del Pino, S., Muñoz, N.A., and Fernández, M. 2019. Litopterna (Mammalia) from the Santa Cruz Formation (Early-Middle Miocene) at Río Santa Cruz, Southern Argentina. In: J.C. Fernicola, M.S. Bargo, S.F. Vizcaíno, and R.F. Kay (Eds.), Early-Middle Miocene Paleontology in the Río Santa Cruz, Southern Patagonia, Argentina. 130 years since Ameghino, 1887. Publicación Electrónica de la Asociación Paleontológica Argentina 19: 170-192.

Scott, W.B. 1903. Mammalia of the Santa Cruz beds. Part I. Edentata. In: W.B. Scott (Ed.), Reports of the Princeton University Expeditions to Patagonia 1896-1899. Vol. 5, Paleontology 2. Princeton University Press, Princeton, p. 1-226.

Scott, W.B. 1904. Mammalia of the Santa Cruz beds. Part I. Edentata. In: W.B. Scott (Ed.), Reports of the Princeton University Expeditions to Patagonia 1896-1899. Vol. 5, Paleontology 2. Princeton University Press, Princeton, p. 227-364.

Simpson, G.G. 1980. Splendid Isolation: the curious history of South American mammals. Yale University Press, New Haven, 266 p.

Sinclair, W.J. 1906. Marsupials of the Santa Cruz beds. In: W.B. Scott (Ed.), Reports of the Princeton University Expeditions to Patagonia, 1896-1899. Princeton University Press, Princeton, 4: 330-460.

Sinclair, W.J. 1909. Mammalia of the Santa Cruz beds. Part I. 
Typotheria. In W.B. Scott (Ed.), Reports of the Princeton University Expeditions to Patagonia, 1896-1899, Princeton University Press, Princeton, p. 1-110.

Trayler, R., Schmitz, M., Cuitiño, J.I., Kohn, M., Bargo, M.S., Kay, R.F., Strömberg, C., and Vizcaíno, S.F. 2019. An improved approach to age-modeling in deep time: Implications for the Santa Cruz Formation, Argentina. GSA Bulletin doi: 10.1130/B35203.1

Vizcaíno, S.F. 2011. Cartas para Florentino desde la Patagonia. Crónica de la correspondencia édita entre los hermanos Ameghino (1887-1902). In: J.C. Fernicola, A. Prieto, and D. Lazo (Eds.), Vida y obra de Florentino Ameghino. Publicación Especial de la Asociación Paleontológica Argentina 12: 51-67.

Vizcaíno, S.F., Bargo, M.S., and Fernicola, J.C. 2013. Expediciones paleontológicas durante los siglos XIX y XX a la Formación Santa Cruz (Mioceno Inferior, Patagonia) y destino de los fósiles. $3^{\circ}$ Congreso Argentino de Historia de la Geología (Salta), Actas: 231-246.

Vizcaíno, S.F., Brinkman, P.D., and Kay, R.F. 2016. On the objectives and results of the Handel T. Martin paleontological expedition (1903-04) to the Santa Cruz Formation in southern Patagonia. Revista del Museo de La Plata, Número Especial 1: 316-333.

Vizcaíno, S.F., De luliis, G., Brinkman, P.D., Kay, R.F., and Brinkman, D.L. 2017. On an album of photographs recording fossils in the "Old collections" of the Museo de la Plata and Ameghino's private collection at the beginning of the 20th century. Publicación Electrónica de la Asociación Paleontológica Argentina 17: 14-23.
Vizcaíno, S.F., Kay R.F., and Bargo, M.S. 2012a. Background for a paleoecological study of the Santa Cruz Formation (late Early Miocene) on the Atlantic Coast of Patagonia. In: S.F. Vizcaíno, R.F. Kay, and M.S. Bargo (Eds.), Early Miocene Paleobiology in Patagonia: high-latitude paleocommunities of the Santa Cruz Formation. Cambridge University Press, Cambridge, p. 1-22.

Vizcaíno, S.F., Kay, R.F., and Bargo, M.S. 2012b. Early Miocene Paleobiology in Patagonia: high-latitude paleocommunities of the Santa Cruz Formation. Cambridge University Press, Cambridge, 370 p.

Vucetich, M.G., Mazzoni, M.M., and Pardiñas, U.F.J. 1993. Los roedores de la Formación Collón Cura (Mioceno Medio), y la Ignimbrita Pilcaniyeu. Cañadón del Tordillo, Neuquén. Ameghiniana 30: 361381.

Doi: 10.5710/PEAPA.18.09.2019.300

Recibido: 11 de julio 2019

Aceptado: 18 de septiembre 2019 